Issue 1/2018

\title{
GENERAL CONSIDERATIONS ON THE IMPACT OF PROPERTY ON THE ECONOMIC AND SOCIAL STATUS OF PEOPLE
}

\author{
Cristiana BANU ${ }^{1}$, Amelia DIACONESCU ${ }^{1}$ \\ ${ }^{1}$ Spiru Haret University, Faculty of Legal, Economic and Administrative \\ Sciences, Craiova, Romania, Email:cristiana_banu@yahoo.com, \\ amy_bbe@yahoo.com
}

\begin{abstract}
Property is indissolubly linked to people's lives, forming part of it, being a permanent problem and occupying a particularly important place in economic, social, political and philosophical science.

Through the structure outlined in this short study, we are also trying to analyze the impact of ownership on people's economic and social status, relative to the concept of property and economic freedom.

So, the impact of property as a multiple social relationship on the social status of people is relevant, namely the link between property and economic freedom, property and social justice, property and equality/inequality in society.
\end{abstract}

Keywords: property; economic freedom; social justice.

JEL Classification: $\mathrm{K}_{40}$

\section{Introduction}

Property has always accompanied the human kind since the dawn of civilization. Man is the only being that, being equipped with ration, took ownership not only on his natural environment, but also on the other beings; on everything that surrounds him, on everything that he discovers and he declared himself a master, applying and requesting other human beings to apply the social norms through power, at the beginning of the local communities and then of the state.

The preoccupation to justify the institution of property has existed in the different stages of the development of the human society, but all the trends and concepts remained unanimous in sustaining its importance and necessity, but the preoccupations differed in regards to its origins and purposes. 


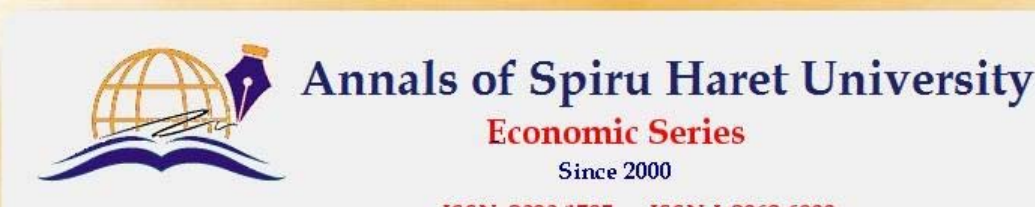

ISSN: 2393-1795 ISSN-L:2068-6900

\section{Issue 1/2018}

Along with the technical and scientific progress, with the considerable increase and diversification of the object of property, the structure of the property report improved. The property evolved, adapting to the new conditions and allowing the continuous development of the market economy. Thus, the pluralism of property ownership has been highlighted, the competition between ownership forms has become more intense, the public domains and the private domains of ownership have overlapped.

The pluralism of the property forms creates the premises for stimulating the initiative, offers unlimited possibilities to act and choose for all the economic agents, through the market tools and mechanisms.

Regarded as economic category, property has always existed throughout the human society, the production and acquisition of goods necessary to live being a mandatory premise for the social life and as such, property is tightly related to the area of material goods production and harvesting the fruits of this activity.

\section{Property and economic freedom}

One of the major issues of the economic science is represented by the definition of the property as complete, multifunctional, fundamental, historically determined social relationship [Bică \&Sandu, 2016]. In this context, explaining the market economy implies a deep analysis of the content of the different forms of property in their unity and compatibility and taking into account their advantages and social-economic limits reported to the optimal functioning of the economic mechanism. But the theoretical premises of such approach for this issue is the general definition of the concept of property, in its multidimensionality and not explaining this concept in a reductionist, economist manner [Bică \& Sandu, 2016].

As Paul Elmer Moore was saying, „for the civilized man, the right to property is more important than the right to life" [Iliescu, 1998].

Starting from this idea, the precursors of the classic political thinking had already seized the special signification that the private property had (known also as personal fortune) for the modern human being. The importance of the property comes firstly from its tight relationship with freedom, tie that, in some of the cases, goes up until identity.

Thus, in the conception of the founders of liberalism, the first form of property - a natural property that is considered to have been gifted by God - is the property on one's own body and person, and this type of property is identified with freedom: slaves were not free because they were not the masters of their own person and on the contrary, the man who is his own master can be named free. 168 


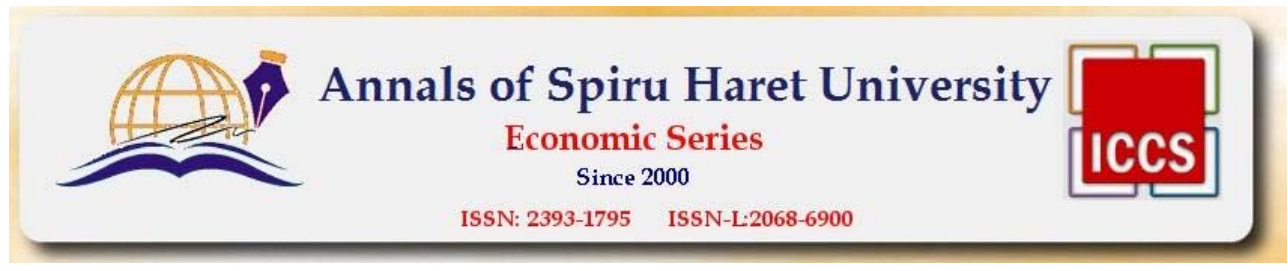

Issue 1/2018

Thus, property means freedom, and a concept based on a freedom cult (such as liberalism) gets, in a perfectly explicable way, to a property cult.

This cult of property can be commented in different ways, but we must keep in mind what is essential, namely, for instance, when we say that property rights are more important than the right to life, we must understand that among these rights we count, in the first place, the right to property on one's own person. So, whoever states the priority of the property on life does not say that owning is more important than being, but only that being your own master is more important than living in any way or ,with any price" [Iliescu, 1998].

As a general rule, the property does not designate the ownership on one's own person, but the possession of certain goods and values and in the liberal vision, this type of property has a natural character. The most important liberal argument in the favour of the private property is its value as guarantee of the modern freedom, even if here we cannot simply talk about an identity between the two; in the world we live in, freedom cannot be separated from property.

As social and economic report, property is characterized by:

- the appropriation or assimilation of a good;

- the owner of the property, who is called a subject, exerts all his attributes or sends, through his will, some of these attributes to others;

- the subject of the property performs his attributes in his interest [Băbeanu, 1993]

With the diversification of the object and the subject of ownership, the internal structure of the economic property ratio was shaped, including the following attributes: the right of the owner to dispose of the property in his possession, his power to dispose, free and unhindered, respectively, the appropriation by a person of a good; the right of possession; the right to use the object of the property in his possession; the right to collect the fruits and advantages of the goods owned; the right to organize, conduct and manage the object of property.

The activity to perform all these attributes of property lay under the responsibility of the owner and actually represents his monopoly, as he is able to totally or partially, temporarily or definitively alienate all these attributes of property. The ways in which the total alienation of the attributes of property occur are:

- the way that occurs on the basis of an equivalent - is the act of selling or buying the asset;

- the way that is done without an equivalent, and thus there is an economic bond of donation; 


\section{Annals of Spiru Haret University \\ Economic Series \\ Since 2000}

ISSN: 2393-1795 ISSN-L:2068-6900

\section{Issue 1/2018}

- the way in which the property attributes of legal successors are passed after the death of the owner; in this situation the report is of inheritance.

In case of separate and temporary alienation of certain attributes of the property, certain specific economic reports pertaining to property take place, such as:

- rent, lease and credit - this is the case when the usage attribute is transmitted for different time periods;

- managerial reports - when transmitting the organization, conduct and management attributes; transmitted.

- usufruct reports - is the case when the fruits harvesting attribute is

An especially important role within the structure of the property is played by its subject, being characterized by the size and elements composing it.

A distinction is being made, from the structural point of view, regarding the property on the production means and the property on consumption goods. Thus, the consumption goods are obtained by using the production mean, so the source of the object of property on the consumption goods is the property on the production means, and the existence or lack of property on the production goods, but also its size has an especially important role in the manifestation of the economic independence or dependence of individuals.

When analyzing the structure and spread of property, in direct relationship with its general object, we have to understand that it allows drafting the concrete historical report between property and freedom.

Within all modern constitutions, property and freedom are considered to be natural and imprescriptible rights of the human being. The report between property and freedom has a special importance, especially from the point of view of the freedom of people regarding their economic activity. Thus humans freedom is translated in their own initiative to be entrepreneurs, in the right they have to consume as they wish the goods from their property, inclusively the labour force, the right to consume or not goods of a certain type, the right to associate in different organizations and economic societies, the human right to donate, to rent, to leave certain goods belonging to them as inheritance.

In the appreciation of freedom, there are several points of view. The first point of view sustains the fact that full economic freedom is achieved only within and based on the individual property, because only such an owner could manifest himself on all level, such as owner, user, manager, beneficiary of the object of property.

The second point of view starts from the fact that the contemporary societies are characterized by economic gigantism and by numerous legal regulations of the 170 

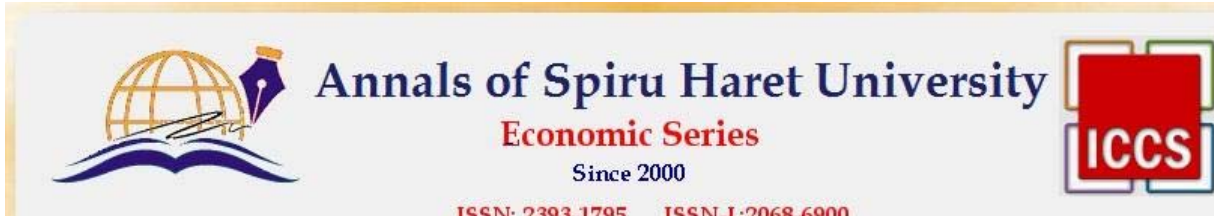

ISSN: $2393-1795 \quad$ ISSN-L-2068-6900

Issue 1/2018

economic activities, which have as result the limitation, more and more pressing, of the individual freedom.

The last point of view, also sustained by Marxism, considers that the full economic freedom of human beings is achieved only within the social property on the production means, manifesting itself based on everyone's freedom and appearing as a conscious behaviour of the individuals, in report with the objective determination of their social-economic life.

The relationship between the concepts of property and economic freedom, in the countries with market economy, is based on three related mechanisms: the first mechanism is the one of free market, the second one is the mechanism of legal regulations and the third mechanism is the one of tradition or habits [Titulescu, 2017]. Based on those three mechanisms, a certain national consensus between people is targeted, also between the economic units and fields of activity, which means economic discipline.

The declared principle of all the Western societies is economic, politic and social liberalism, this being a relative principle, under no circumstance an absolute one, because:

a) private property and market economy disseminate economic power, but not equally to all economic agents, because there is a tendency to enrich certain individuals or corporations, and they have a great political and social influence;

b) private property has a great preponderance, yet it does not separate the economic power from the political power of the state, but this separation is not complete, and the degree of measurement of these powers does nothing else than to show the degree of freedom of individuals;

c) in Western societies there are dysfunctions in the relationships between the individual and the society, and some phenomena take place challenging certain rules on which the social-economic system is based and rules that do not respect the freedom of other individuals, organizing anti-social manifestations and rejecting any intervention that comes from the legal authorities, confusing liberalism or the free society with the so-called permissive society.

Starting from all these considerations, liberalism permanently leads a private property defence politic in order to reject nationalizations. A high portion of the economic success obtained by privatization, eradication of economic monopoly and reduction of the state authoritative intervention and by encouraging the competition between owners - entrepreneurs are linked, in this way, to the liberal politics of promoting private property. 


\section{Issue 1/2018}

\section{Property and social justice}

A very important issue is referring to the economic inequality and social injustice. In the social reality, everything is established simultaneously: organization of production is one of the causes of inequality and the feeling of injustice is one of the possible road blockers of the economy.

Many years ago, the developed countries raised the issue of coexistence of wealth and poverty, this representing an important issue in the contemporary times too.

Different calculations were made, which led to the conclusion that it would take $2 \%$ of the GDP to make poverty disappear. Thus, there are certain inequalities, which we can all agree upon [Titulescu, 2016]. Inequality is mistaken with injustice and action on the results from economy means action on the system itself and in this way, the social order is shaken. The following are considered as being inequality laws [Didier, 1994].

- The difference between the monthly revenue. There are differences between possessions, even higher than income inequalities. In the situation where no one can survive without a minimum income, it is possible to live without saving and without the accumulation of the lowest patrimony.

- The economic inequalities are reflected in the way of living. For example, more than $80 \%$ of the liberal professions and senior executives go on vacation. This is only the case of a worker in two, because there are inequalities in working conditions. Most often, there are differences in salary, differences in "security" and the difference in interest for work.

- Inequality in front of death. This law of inequality is reflected in the fact that, for example, at 35, teachers, members of the liberal professions have another 40 years of living, while agricultural workers and skilled workers have 5 years less to live. Therefore, in some professions, one lives worse and dies earlier.

- Inequalities are cumulated. To illustrate the linking of inequalities, some authors compared the destinies of different people. For example, Catherine BlumGirardeau compared the destiny of a skilled worker's son to the destiny of a manager's son, relying on some of the observed realities. This comparison illustrates how inequalities accumulate, following a trajectory that we can call circular: at every stage of life, a less advantageous social position from the beginning gives fewer chances of success in life, and chances of success reduce the hope of social promotion.

An important objection to the law of General Equality is that it isn't compatible with the economic freedom to venture, succeed and own, representing an issue that is not meant to disappear even for more social justice. 


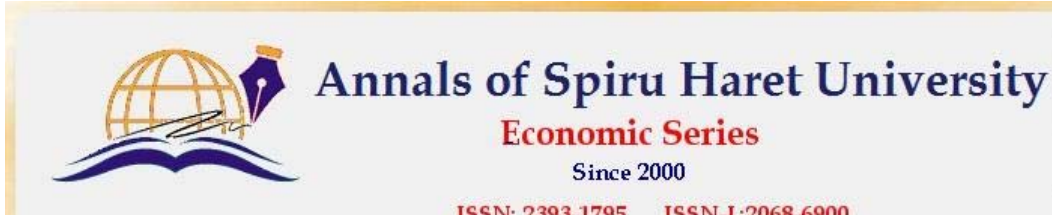

ISSN: 2393-1795 ISSN-I-2068-6900

Issue 1/2018

In this way, referring to property, we can definitely state the fact that private property has not always served freedom and some limitations of the private property have clearly determined the progress of freedom.

In an economy where the means of production are the real estate goods that are part of the state property, the individual freedom is in a bad position. However good the intentions of politic power are, when the spontaneous competition of people cannot manifest itself any longer, it is oriented towards the public obligations and everything that pertains to exercising a power on a fellow human being. In the entire history of mankind, confiscations and loss of freedom went hand in hand, and in the situation when property is no longer guaranteed, the resort of economic progress is broken.

As a conclusion, we may say that the free initiative and market are generating inequalities. Certain inequalities are considered to be normal, some of them are unjust and unacceptable. But the liberal capitalism is also creator of valuables. If they are too limited, there is a risk of diminishing the values to be distributed, which leads to the loss of all.

Another conclusion is that economic freedom is one of the points of support for individual freedom.

Any excessive restriction of economic freedoms makes people more vulnerable, and so the individual has limited freedom. It is precisely for this reason that, in liberal democracies, states intervene to maintain a balance between economic efficiency, individual freedom and social justice, seeking to correct inequalities through social assistance and redistribution; but the optimum balance is very hard to find.

\section{Property, between justice and equality}

Because property represents one of the main fundamental human rights, it is considered a person's legal right, which must be mandatorily respected, we believe that it is necessarily imposed to make a brief comparison between justice and equality, because we consider that the notion of property has a tight relation with these. Thus, justice was considered as the ethical and legal value, depending on which the social relationships and legal reports, legal norms and decisions of the jurisdiction organs existing in a certain era and given social organization are approved or not approved. We also believe that justice represents the fact of recognizing one's rights and granting every individual what is his, namely, what he should legitimately and legally have. And last but not least, we think that justice represents a moral virtue, one of the highest four cardinal virtues as it is considered, consisting of giving every individual what belongs to him. 


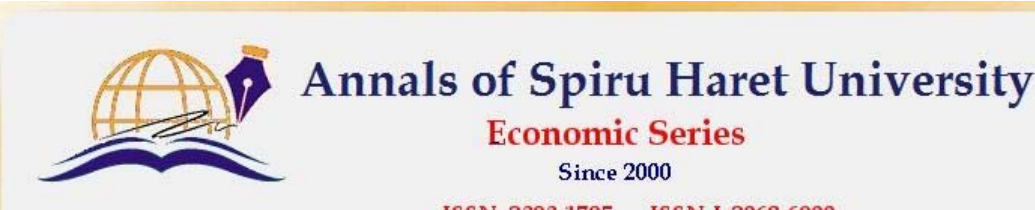

ISSN: 2393-1795 ISSN-L:2068-6900

\section{Issue 1/2018}

Over the time, especially in the societies based on exploitation, the dominant classes seek to justify, by their own conceptions on justice, the existing economic relationships and to empower them through moral laws and norms. In exchange, the oppressed classes and layers of society promoted their own concepts on justice, which put a high accent on the change of the respective social relationships and on the will of the masses to mandatorily eliminate social inequality.

Several conceptions on justice took shape, but one which is still hiding the essence. One of the most important bourgeois conceptions on justice is the one belonging to Marxism-Leninism, which conceived a new theory, considered to be scientifically communist, according to which the true social justice consists in the release of the man from any form of exploitation and oppression and in the achievement of the complete social equality, under the conditions of communism. Although there are several forms of justice, the main categories are:

- distributive justice, representing the correctness of the access to resources, positions in the society, division of certain advantages, obligations among persons, groups in the society, etc.;

- procedural justice, which implies the abidance by the laws, but also the complete fulfilment of justice. Regarding the abidance by the laws and the complete fulfilment of justice, justice implies respecting the legal rights of a person, among which we remind: personal freedom, property, human dignity;

- corrective or reconstructive justice represents the last, but not least important category of justice; it consists in the repair of injustice and correctness of the reaction to injustice and prejudices.

By expressing all these views, we believe that we can reach a clear conclusion, which leads us to the fact that, as one of the legal rights of modern man, property is at the border between justice and equality.

The compatibility of ownership forms, the mutations taking place in the structure of the property system are the expression of a historical necessity, the possibility of embodying the forms of ownership in the rules of functioning of the market economy. Thus, private economic units must be supported by the state with economic levers and an appropriate legal framework for the free initiative and creativity of entrepreneurs. In turn, the public sector must rely on the private sector, which provides an important source of budget through all the taxes and fees paid, which can be redistributed in the public interest or to meet growing social needs in education and culture, the social and health system, the state defence system. [Tobă, 2003] 


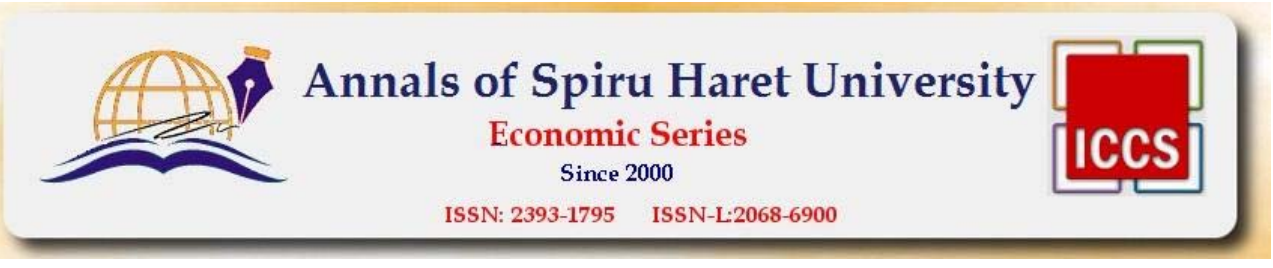

Issue 1/2018

\section{Conclusions}

During the transition period, the ownership structure underwent major changes in Romania, it was renewed and the private sector developed in the economy; the functional mechanism of the economy is based in particular on private property; the majority of enterprises are private companies or economic agents holding private majority capital; industry, agriculture, construction, commerce and services mainly operate on the basis of private property. The changes in the nature and the structure of property created the freedom to decide and act for the economic agents, and the economic environment became appropriate for the free market economy, which determined the European Union to recognize the existence of functional market economy in Romania. But this does not mean that the market economy and, within it, the private property are at the same level like in the developed countries from the European Union, since there are still some discrepancies in the process of creating the private sector, which must be fixed in the current stage of consolidating the Romanian market economy.

\section{References}

1. Bică, G. \& Sandu, I., Economie (Craiova: Sitech, 2016).

2. Bică, G. \& Sandu, I., Introducere în economie şi politici economice (Craiova: Sitech, 2016).

3. Iliescu, A., Liberalismul între succese şi iluzii (Bucharest: All, 1998).

4. Băbeanu, M., Economie politică, vol. I (Craiova: Reprografia, 1993).

5. Didier, M., Economia. Regulile jocului, ed. II (Bucharest: Humanitas, 1994).

6. Titulescu, P., "Unfair Competitive Practices Generating Disruptions in Inter-State Economic Circuits. Regulations between Present and Future," Law and Public Administration, Volume III, Issue 6 (Craiova: 2017).

7. Titulescu, P., "Summary Statement on the Elements of Interference and Influence of Commercial Law and Competition Law," Law and Public Administration, Volume II, Issue 4 (Craiova: 2016).

8. Tobă, D., Teorie economică general (Craiova: Universitaria, 2003). 
